\title{
KEEFEKTIFAN MEDIA KOIN BILANGAN DAN GARIS BILANGAN MENGGUNAKAN PENDEKATAN MATEMATIKA REALISTIK
}

\section{THE EFFECTIVENESS OF NUMERAL COIN AND NUMBER LINE MEDIA USING REALISTIC MATHEMATICS APPROACH}

\author{
Awal Nur Kholifatur Rosyidah ${ }^{1}$ Hartono $^{2}$ \\ ${ }^{1}$ Prodi PGSD, FKIP, Universitas Mataram \\ ${ }^{2}$ Prodi Pendidikan Matematika FMIPA Universitas Negeri Yogyakarta \\ 1awal_rosyidah@unram.ac.id, ${ }^{2}$ hartono@uny.ac.id
}
Pengutipan: Rosyidah, A. N. K., \& Hartono. (2019). Keefektifan media koin bilangan dan garis bilangan menggunakan pendekatan matematika realistik. Pedagogi: Jurnal Penelitian Pendidikan, 6 (2), hlm 1-14.

Diajukan: 31-10-2019

Diterima: 28-11-2019

Diterbitkan: 01-12-2019

\begin{abstract}
ABSTRAK
Penelitian ini bertujuan untuk mendeskripsikan: 1) keefektifan pembelajaran menggunakan media koin bilangan dengan pendekatan PMRI; 2) keefektifan pembelajaran menggunakan media garis bilangan dengan pendekatan PMRI; 3) manakah yang lebih efektif antara kedua media pembelajaran ditinjau dari prestasi belajar dan tanggung jawab terhadap matematika siswa kelas V SD di gugus II Sleman. Penelitian ini termasuk dalam jenis penelitian kuasi eksperimen. Populasi penelitian adalah seluruh kelas V SD di gugus II Sleman. Sampel penelitian ditentukan secara acak, terpilih siswa kelas V SDN Caturharjo dan siswa kelas VB SDN Keceme 1. Uji beda menggunakan MANOVA. Pengujian keefektifan pembelajaran menggunakan uji $T^{2}$ Hotteling's satu populasi dan one sample t-test. Hasil penelitian menunjukkan bahwa: 1) pembelajaran menggunakan media koin bilangan dengan pendekatan PMRI efektif ditinjau dari prestasi belajar dan tanggung jawab terhadap matematika; 2) pembelajaran menggunakan media garis bilangan dengan pendekatan PMRI efektif ditinjau dari prestasi belajar dan tanggung jawab terhadap matematika; 3) pembelajaran matematika menggunakan media koin bilangan dengan pendekatan PMRI lebih efektif dibandingkan media garis bilangan ditinjau dari prestasi belajar matematika. Namun, sama efektifnya ditinjau dari tanggung jawab terhadap matematika. Penggunaan koin bilangan dan garis bilangan dapat dijadikan sebagai jembatan dari masalah real ke dalam matematika formal, sehingga memberikan dampak positif terhadap pencapaian prestasi belajar.
\end{abstract}

Kata Kunci: koin bilangan, garis bilangan, PMRI, prestasi belajar, tanggung jawab

\section{ABSTRACT}

This research was aimed to describe: 1) learning effectiveness using numeral coin media with PMRI approach; 2) learning effectiveness using numeral line media with PMRI approach; and 3) the most effective learning media from those two that is observed from learning achievement and responsibility attitude of elementary school grade $V$ students in cluster II Sleman. This research belongs to quasi experiment. The population of this research was all of grade V students of elementary schools in cluster II Sleman. The sample in this research was chosen randomly, grade V students in Elementary School Caturharjo and grade $V B$ students in Elementary School Keceme 1. To test the difference in the effectiveness, 
MANOVA was employed. Then $T^{2}$ Hotteling's test of one population and one sample t-test method was employed to determine which method was more effective. The result of the research shows that: 1) the learning activity using numeral coin media with PMRI approach is effective observed from learning achievement and responsibility attitude towards mathematics; 2) the learning activity using numeral line media with PMRI approach is effective observed from learning achievement and responsibility attitude towards mathematics; 3) mathematics learning using numeral coin media with PMRI approach is more effective than numeral line media observed from mathematics learning achievement. However, mathematics learning using numeral coin media with PMRI approach is as effective as mathematics learning using numeral line with PMRI approach observed from responsibility towards mathematics. The use of numeral coin media and numeral line media can be used as a bridge from real problems into formal mathematics, thus giving a positive impact on learning achievement.

Keywords: numeral coin, number line, realistic mathematics, learning achievement, responsibility

\section{PENDAHULUAN}

Pendidikan menjadi salah satu sektor yang sangat penting dalam pengembangan sumber daya manusia. Berbagai pembaharuan dilakukan untuk meningkatkan kualitas pendidikan seperti pembaharuan kurikulum, perubahan sistem penilaian, pengembangan pendekatan dan model pembelajaran, pembaharuan metode belajar serta media pembelajaran. Dimulai dari tingkatan Sekolah Dasar, kualitas pendidikan harus diperbaiki. Pemberian konsep harus diberikan secara benar pada tingkatan SD, seperti pada mata pelajaran matematika.

Matematika di tingkat Sekolah Dasar hakikatnya memberikan pengalaman belajar terhadap anak dalam hal bermatematika sesuai dengan tahapan perkembangan. Matematika SD dikatakan sebagai pondasi belajar untuk jenjang yang lebih tinggi sehingga penting untuk diperhatikan, yang kemudian diharapkan akan terjadi peningkatan prestasi belajar matematika. Faktanya saat ini matematika manjadi salah satu pelajaran yang kurang disukai oleh siswa. Konsep matematika merupakan konsep abstrak, terlebih lagi KD operasi hitung bilangan bulat. Sementara pola pikir siswa SD berada pada tahap operasional kongkrit. Siswa perlu diupayakan untuk memahami matematika sesuai dengan tingkat perkembangannya.

Materi bilangan bulat menjadi salah satu materi yang abstrak untuk bisa dipahami siswa. Letak keabstrakannya dilihat dari bilangan bulat negatif yang implementasinya jarang digunakan dalam kehidupan sehari-hari, sehingga siswa cenderung keliru dalam menentukan hasil penjumlahan maupun pengurangannya. Berdasarkan hasil wawancara terhadap beberapa guru kelas V SD di Gugus II Sleman, banyak siswa yang kesulitan untuk memahami operasi hitung bilangan bulat, terlebih lagi jika sudah mencampurkan bilangan negatif di dalamnya. Sebagai contoh, $-5+2=-3$, kebanyakan siswa menjawab -7 karena masih terpengaruh pada penjumlahan bilangan asli. Contoh lain adalah operasi pengurangan $-7-3=-10$, kebanyakan siswa menjawab -4 karena masih terpengaruh pada pengurangan bilangan asli. Selama ini guru mengajarkan operasi hitung bilangan bulat sebatas pada buku teks, sehingga terasa kurang maksimal cara guru di dalam membelajarkan materi tersebut kepada siswa. Akibatnya penguasaan dan pemahaman konsep bilangan bulat masih kurang dipahami dengan baik.

Cara mengajar guru yang demikian mengakibatkan rendahnya prestasi belajar matematika siswa kelas V SD. Banyak faktor yang mempengaruhi prestasi belajar matematika, seperti sikap tanggung jawab dalam belajar masih kurang diaplikasikan. Berdasarkan pengamatan, banyak siswa bermain sendiri, sebagian besar siswa cenderung kurang aktif dalam mengikuti pelajaran, dan keberanian siswa mengerjakan soal matematika di depan 
kelas masih kurang. Siswa cenderung mengabaikan tugas jika kurang mendapatkan pengawasan guru dan terkadang ada yang tidak mengerjakan PR matematika yang diberikan guru. Hal ini menunjukkan kurangnya kesadaran seperti tanggung jawab dan dorongan dalam diri siswa sendiri untuk dapat mencapai prestasi yang lebih baik.

Penguasaan tanggung jawab menjadi penting ditekankan untuk siswa SD dikarenakan agar terlatih mempunyai kewajiban terhadap tugas belajarnya. Carpenter \& Pease (2013: 38) berpendapat bahwa "we assert that students must assume greater responsibility for their learning in order to attain deep understanding and transferable skills that benefit them throughout their lives". Maksudnya adalah siswa harus bertanggung jawab lebih besar pada tugas belajarnya. Hal ini dimaksudkan untuk mencapai pemahaman yang mendalam dan pemerolehan keterampilan bagi siswa itu sendiri. Oleh karena itu, tanggung jawab siswa harus dibiasakan dengan mulai melaksanakan pekerjaan maupun tugas dengan sebaikbaiknya sesuai dengan kemampuan di lingkungan keluarga dan lingkungan sekolah.

Prestasi belajar siswa dipengaruhi secara langsung oleh karakteristik siswa dan pengalaman belajarnya. Peran guru bukan mentransfer pengetahuan tetapi sebagai fasilitator dalam belajar. Menghadapi kondisi ini, pembelajaran matematika harus menyeimbangkan pada aspek kognitif dan afektif. Bentuk inovasi pembelajaran matematika untuk memperbaiki keadaan tersebut yaitu penerapan pendekatan Pendidikan Matematika Realistik Indonesia (PMRI). PMRI sebagai hasil adaptasi dari Realistic Mathematics Education yang diselaraskan dengan kondisi budaya, geografis, dan kehidupan masayarakat Indonesia. Pendekatan PMRI diharapkan dapat memberikan kebebasan siswa dalam menyelesaikan masalah matematika. Sesuai pendapat Widyastuti \& Pujiastuti (2014: 185) bahwa dalam membelajarkan konsep matematika, pendekatan PMRI dilakukan dengan mengaitkan hal-hal secara realistik yang dapat dibayangkan siswa. Tidak cukup hanya mengetahui dan menghafal, tetapi dibutuhkan suatu pemahaman serta kemampuan menyelesaikan persoalan matematika melalui benda real sebagai bentuk pengalaman manusia. Pendapat tersebut, menekankan hal terpenting dalam pembelajaran matematika bukan hasil, tetapi proses yang digunakan siswa dalam melakukan eksplorasi dan menyelesaikan masalah matematika.

PMRI memberikan kesempatan bagi siswa untuk lebih aktif dan kreatif, serta dapat meningkatkan aktivitas belajar dan pencapaian prestasi belajar siswa. Freudenthal (Zulkardi, 2002: 9) menjelaskan bahwa "RME has its own philosophy and characteristics. It incorporates views on what mathematics is, how students learn mathematics, and how mathematics should be taught. The philosophy of RME is strongly influenced by Hans Freudenthal concept of mathematics education as a human activity". RME menggabungkan pandangan tentang apa itu matematika, bagaimana siswa belajar matematika, dan bagaimana matematika harus diajarkan, dikarenakan filosofi dari RME dipengaruhi oleh konsep pendidikan matematika sebagai aktivitas manusia.

Permasalahan yang sesuai dengan realita pada PMRI, digunakan sebagai titik awal pengembangan ide dan konsep matematika. Menurut Uzel \& Uyangor (2006: 1952) terdapat hal penting yang menjadi inti dari matematika realistik yaitu matematika harus dihubungkan dengan realita, "mathematics must be close to children and be relevant to everyday life situations". Hal-hal yang relevan dengan kehidupan sehari-hari dapat membantu menjelaskan tujuan dari materi matematika dan membuatnya lebih bermakna. Proses pembelajaran matematika dengan konteks dunia nyata menjadikan lebih bermakna dikarenakan siswa belajar untuk berpikir sesuai dengan konteks dan mendapatkan pengalaman dari sesuatu yang telah dipelajarinya.

Pembelajaran matematika realistik menurut Treffers (Wijaya, 2012: 43) membedakan dua tingkat matematisasi, yaitu matematisasi horizontal dan matematisasi vertikal. Matematisasi dalam pembelajaran matematika adalah suatu proses peningkatan dan 
pengembangan ide matematika secara bertahap. Pada matematisasi horizontal, diawali dengan pengidentifikasian konsep matematika berdasarkan keteraturan dan hubungan yang ditemukan melalui proses penyelesaian masalah informal. Sedangkan matematisasi vertikal merupakan proses formalisasi, di mana model matematika yang diperoleh pada matematisasi horizontal menjadi landasan dalam pengembangan konsep matematika yang lebih formal. Sehingga pada tahap ini siswa diberi kebebasan menyelesaikan masalah matematika dengan caranya sendiri.

Proses pembelajaran memerlukan suatu perkembangan dalam menyampaikan informasi kepada siswa, salah satunya adalah media pembelajaran. Penggunaan media pembelajaran akan lebih efektif dilaksanakan, jika siswa turut serta dalam mendemonstrasikan secara langsung. Jenis media pembelajaran yang dapat dimanfaatkan sebagai konteks dalam belajar matematika yang memuat operasi hitung bilangan bulat adalah media pencacah dengan dua warna yang berbeda dan garis bilangan (van de Walle, 2008: 241). Media pencacah dua warna berbeda disebut juga dengan koin bilangan. Pemilihan dua media tersebut disesuaikan dengan karakteristik siswa SD, sehingga akan membantu pemahaman siswa terhadap materi. Hal ini dirasa sangat membantu guru dan siswa untuk memahami konsep bilangan bulat yang bersifat abstrak.

Koin bilangan menekankan pada konsep tentang bilangan kardinal, berarti bilangan tersebut mewakili sejumlah objek tertentu. Sementara garis bilangan menekankan pada konsep tentang bilangan ordinal, berarti bilangan tertentu mewakili posisi relatif terhadap bilangan lain (Steiner, 2009: 9).Melalui penggunaan media koin bilangan dan garis bilangan siswa akan belajar berhitung tentang konsep operasi hitung penjumlahan dan pengurangan yang diawali dari permasalahan sehingga sesuai dengan konteks apa yang dapat ditemukan dalam kehidupan sehari-hari siswa. Pengorganisasian melalui permasalahan yang bersifat kontekstual dengan dibantu oleh demonstrasi media koin bilangan dan garis bilangan, akan membawa siswa melalui pengalaman belajar yang sesuai dan terorganisir dari suatu konsep ke konsep berikutnya. Kondisi ini akan sangat membantu siswa dalam membentuk struktur matematika.

Pada proses pembelajaran, siswa akan berdiskusi dalam kelompok kecil sembari mendemontrasikan koin bilangan dan garis bilangan untuk menyelesaikan soal. Siswa berbagi tanggung jawab dengan siswa lainnya, termasuk dengan guru untuk menciptakan suasana belajar dan berusaha memenuhi tugas pengembangan keterampilan dan penguasaan kompetensi yang dipelajari. Siswa akan belajar lebih banyak melalui proses matematisasi, berdiskusi, dan berbagi pengetahuan. Hal ini sesuai dengan pembelajaran yang diharapkan dapat memberikan kesempatan siswa untuk mencapai prestasi belajar dan tanggung jawab siswa terhadap matematika.

Terkait dengan permasalahan tersebut, penelitian ini bertujuan untuk mendeskripsikan keefektifan pembelajaran matematika menggunakan media koin bilangan dengan pendekatan PMRI, media garis bilangan dengan pendekatan PMRI, serta membandingkan keefektifan pembelajaran menggunakan media koin bilangan dan garis bilangan dengan pendekatan PMRI ditinjau dari prestasi belajar dan tanggung jawab terhadap matematika.

\section{METODE PENELITIAN}

Jenis penelitian ini adalah quasi eksperimen menggunakan pretest-posttest nonequivalent comparison-group design, yang bertujuan membandingkan dua perlakuan yang berbeda kepada subjek penelitian. Metode eksperimen dipilih karena pembelajaran matematika yang dirancang belum diketahui keefektifannya, kemudian dibandingkan hasilnya. Pembelajaran matematika dirancang menggunakan media koin bilangan dan garis 
bilangan dengan pendekatan PMRI, kemudian dilakukan percobaan untuk diketahui keefektifannya ditinjau dari prestasi belajar dan tanggung jawab siswa terhadap matematika.

Penelitian ini dilaksanakan di SDN Caturharjo dan SDN Keceme 1, Sleman pada kelas V. Kelas V SDN Caturharjo sebagai kelompok eksperimen pertama, yang diberikan perlakuan pembelajaran menggunakan media koin bilangan dengan pendekatan PMRI. Kelas VB SDN Keceme 1 sebagai kelompok eksperimen kedua, yang diberikan perlakuan pembelajaran menggunakan media garis bilangan dengan pendekatan PMRI. Waktu penelitian dilaksanakan pada semester Gasal 2016/2017 pada bulan Oktober-November 2016.

Populasi dalam penelitian ini adalah seluruh siswa kelas V SD di Gugus II Sleman pada semester Gasal 2016/2017 yang berjumlah 187 siswa. Pengambilan sampel menggunakan teknik cluster random sampling. Sampel diambil berdasarkan cluster kelas. Tahap pertama, menyusun cluster berupa sekolah, yaitu mengambil secara acak dua dari tujuh SD di gugus II Sleman, sehingga terpilih SDN Caturharjo dan SDN Keceme 1. Selanjutnya diambil secara acak untuk menentukan kelas yang akan dijadikan sampel penelitian. Rancangan penelitian menggunakan desain pretest-posttest nonequivalent comparison-group design.

Tabel 1. Desain Penelitian

\begin{tabular}{cccc}
\hline $\mathbf{G}_{\mathbf{1}}$ & $\mathbf{O}_{\mathbf{1}}$ & $\mathbf{X}_{\mathbf{1}}$ & $\mathbf{O}_{\mathbf{3}}$ \\
$\mathbf{G}_{\mathbf{2}}$ & $\mathrm{O}_{2}$ & $\mathrm{X}_{2}$ & $\mathrm{O}_{4}$ \\
\hline \multicolumn{3}{c}{ (Johnson \& } & Christensen, 2014: 359)
\end{tabular}

Keterangan:

$\mathrm{G}_{1} \quad$ : Kelompok A

$\mathrm{G}_{2} \quad$ : Kelompok B

$\mathrm{O}_{1} \quad$ : Pretest Kelompok A

$\mathrm{O}_{2} \quad$ : Pretest Kelompok B

$\mathrm{O}_{3} \quad$ : Posttest Kelompok A (prestasi dan tanggung jawab)

$\mathrm{O}_{4} \quad$ : Posttest Kelompok B (prestasi dan tanggung jawab)

$\mathrm{X}_{1}$ : $\quad$ Perlakuan 1 (Pembelajaran menggunakan media koin bilangan dengan pendekatan PMRI)

$\mathrm{X}_{2}$ : Perlakuan 2 (Pembelajaran menggunakan media garis bilangan dengan pendekatan PMRI)

Teknik yang digunakan dalam proses pengumpulan data adalah tes dan non tes, yang diberikan sebelum perlakuan (pretest) dan setelah perlakuan (posttest). Instrumen yang digunakan adalah tes, angket, dan lembar observasi. Tes prestasi digunakan untuk mengukur prestasi belajar matematika. Materi tes adalah operasi hitung bilangan bulat kelas V semester 1. Angket digunakan untuk mengukur tanggung jawab siswa terhadap matematika. Lembar observasi digunakan untuk mengamati aktivitas siswa selama pembelajaran dan mengetahui persentase keterlaksanaan pembelajaran menggunakan media koin bilangan dan garis bilangan dengan pendekatan PMRI.

Data tes prestasi belajar operasi hitung bilangan bulat dan data angket tanggung jawab siswa terhadap matematika dari hasil pretest maupun posttest selanjutnya dihitung nilai rataratanya, diinterpretasi ke dalam kriteria yang ditetapkan dan ditentukan persentasenya. Data prestasi belajar operasi hitung bilangan bulat diperoleh melalui pengukuran dengan instrumen tes yang berbentuk soal jawab singkat dan uraian berjumlah 22 soal. Hasil yang diperoleh dikonversi sehingga menjadi nilai dengan rentang antara 0 sampai dengan 100. Skor tersebut kemudian digolongkan dalam kriteria berdasarkan KKM yang ditetapkan sekolah. Data sikap tanggung jawab siswa terhadap matematika diperoleh melalui angket yang berisi 27 item pernyataan. Setelah diperoleh data tanggung jawab siswa, total skor dikatagorikan berdasarkan pada Tabel 2. 
Tabel 2. Kriteria Tanggung Jawab Siswa Terhadap Matematika

\begin{tabular}{llc}
\hline \multicolumn{1}{c}{ Interval } & \multicolumn{1}{c}{ Interval Skor } & Kriteria \\
$\mathrm{Mi}+1,5 \mathrm{Si}<X \leq \mathrm{Mi}+3 \mathrm{Si}$ & $108<X \leq 135$ & SangatTinggi \\
$\mathrm{Mi}+0,5 \mathrm{Si}<X \leq \mathrm{Mi}+1,5 \mathrm{Si}$ & $90<X \leq 108$ & Tinggi \\
$\mathrm{Mi}-0,5 \mathrm{Si}<X \leq \mathrm{Mi}+0,5 \mathrm{Si}$ & $72<X \leq 90$ & Sedang \\
$\mathrm{Mi}-1,5 \mathrm{Si}<X \leq \mathrm{Mi}-0,5 \mathrm{Si}$ & $54<X \leq 72$ & Rendah \\
$\mathrm{Mi}-3 \mathrm{Si} \leq \mathrm{X} \leq \mathrm{Mi}-1,5 \mathrm{Si}$ & $27 \leq \mathrm{X} \leq 54$ & SangatRendah \\
\hline
\end{tabular}

(Saifuddin Azwar, 2011: 163)

Keterangan:

$\begin{array}{ll}\mathrm{X} & : \text { Total skor aktual } \\ \mathrm{Mi} & : 1 / 2(\text { skor maksimum ideal }+ \text { skor minimum ideal }) \\ \mathrm{Si} & : 1 / 6(\text { skor maksimum ideal }- \text { skor minimum ideal })\end{array}$

Analisis keefektifan pembelajaran dilakukan untuk menunjukkan tingkat pencapaian tujuan pembelajaran yang difokuskan pada pengukuran variabel yang telah didefinisikan. Pembelajaran matematika efektif jika nilai rata-rata kelas yang diperoleh siswa lebih dari 65 . Sedangkan pembelajaran dikatakan efektif ditinjau dari tanggung jawab terhadap matematika ketika skor siswa temasuk pada kategori tinggi yaitu lebih dari 90.

Mengetahui keefektifan dari masing-masing pembelajaran menggunakan media koin bilangan dan garis bilangan dengan pendekatan PMRI ditinjau dari prestasi belajar dan tanggung jawab, maka digunakan one sample t-test. Selanjutnya untuk mengetahui perbedaan keefektifan antara kedua kelas tersebut digunakan uji MANOVA $\left(T^{2}\right.$ Hotteling $\left.^{\prime} s\right)$ dengan kriteria keputusan pada taraf signifikansi 5\%. Jika hasil uji MANOVA menunjukkan terdapat perbedaan keefektifan antara kedua kelompok perlakuan, maka dilanjutkan analisis lanjutan menggunakan uji independent sample t-test untuk mengetahui perlakuan mana yang lebih efektif ditinjau dari kedua variabel terikat (prestasi dan tanggung jawab). Sebelum dilakukan uji MANOVA terlebih dahulu harus dipenuhi dua asumsi multivariat yaitu asumsi kenormalan multivariat dan asumsi homogenitas multivariat. Pemeriksaan normalitas dilakukan dengan cara nilai jarak Mahalanobis $\left(d_{i}{ }^{2}\right)$. Sementara uji homogenitas dilakukan melalui uji Box'M. Pengujian dilakukan menggunakan bantuan SPSS 21 for windows.

\section{HASIL PENELITIAN DAN PEMBAHASAN}

Data yang diperoleh dalam penelitian ini yaitu data prestasi belajar operasi hitung bilangan bulat dan sikap tanggung jawab siswa terhadap matematika. Tabel 3 menyajikan deskripsi data prestasi belajar matematika materi operasi hitung bilangan bulat.

Tabel 3. Deskripsi Data Prestasi Belajar Matematika

\begin{tabular}{ccccc}
\hline \multirow{2}{*}{ Deskripsi } & \multicolumn{2}{c}{$\begin{array}{c}\text { PMRI-Koin } \\
\text { Bilangan }\end{array}$} & \multicolumn{2}{c}{$\begin{array}{c}\text { PMRI-Garis } \\
\text { Bilangan }\end{array}$} \\
\cline { 2 - 5 } & Pretest & Posttest & Pretest & Posttest \\
\hline Rata-rata & 54,67 & 78,95 & 47,39 & 71,13 \\
Skor Tertinggi & 92 & 100 & 76 & 90 \\
Skor Terendah & 32 & 60 & 28 & 58 \\
Nilai maksimum ideal & 100 & 100 & 100 & 100 \\
\hline
\end{tabular}


Berdasarkan data pada Tabel 3, terlihat bahwa setelah perlakuan (posttest) terjadi peningkatan prestasi belajar matematika baik di kelas PMRI-Koin Bilangan maupun kelas PMRI-Garis Bilangan dengan rentang peningkatan yang berbeda. Kelas dengan pembelajaran menggunakan media koin bilangan dengan pendekatan PMRI rata-rata skor meningkat 24,28 yaitu dari skor awal 54,67 menjadi 78,95. Sedangkan pada kelas dengan pembelajaran menggunakan media garis bilangan dengan pendekatan PMRI peningkatan skor yang terjadi sebesar 23,74 yaitu dari skor awal 47,39 menjadi 71,13.

Deskripsi data sikap tanggung jawab siswa terhadap matematika untuk kedua kelas eksperimen disajikan pada Tabel 4.

Tabel 4. Deskripsi Data Sikap Tanggung Jawab Terhadap Matematika

\begin{tabular}{ccccc}
\hline \multirow{2}{*}{ Deskripsi } & \multicolumn{2}{c}{ PMRI } & \multicolumn{2}{c}{ PMRI } \\
& \multicolumn{2}{c}{ Koin Bilangan } & \multicolumn{2}{c}{ Garis Bilangan } \\
\cline { 2 - 5 } & Pretest & Posttest & Pretest & Posttest \\
\hline Rata-rata & 87,81 & 101,52 & 89,13 & 99,96 \\
Skor Tertinggi & 114 & 130 & 119 & 128 \\
Skor Terendah & 62 & 73 & 58 & 68 \\
Nilai Maksimum Ideal & 135 & 135 & 135 & 135 \\
Nilai Minimum Ideal & 27 & 27 & 27 & 27 \\
\hline
\end{tabular}

Berdasarkan data pada Tabel 4, rata-rata skor angket sikap tanggung jawab siswa sebelum perlakuan (pretest) pada kelas PMRI-Koin Bilangan adalah 87,81 yang masuk dalam interval $72<X \leq 90$ atau berada pada katagori sedang dan pada kelas PMRI-Garis Bilangan adalah 89,13 juga berada pada interval yang sama atau termasuk katagori sedang. Sedangkan ratarata skor angket sikap tanggung jawab siswa setelah perlakuan (posttest) pada kelas PMRIKoin Bilangan adalah 101,52 yang masuk dalam interval $90<X \leq 108$ atau berada pada kategori tinggi dan pada kelas PMRI-Garis Bilangan adalah 99,96 juga berada pada interval yang sama atau termasuk kategori tinggi. Nampak bahwa pada kedua kelas tersebut terjadi peningkatan rata-rata skor sebelum dan setelah perlakuan. Kelas dengan pembelajaran PMRIKoin Bilangan rata-rata skor meningkat sebesar 13,71 yaitu dari skor awal 87,81 menjadi 101,52. Sedangkan pada kelas dengan pembelajaran PMRI-Garis Bilangan peningkatan skor yang terjadi sebesar 10,83 yaitu dari skor awal 89,13 menjadi 99,96.

Data penelitian ini selanjutnya dianalisis untuk mengetahui keefektifan dari masingmasing kelompok pembelajaran terhadap prestasi belajar operasi hitung bilangan bulat dan tanggung jawab siswa terhadap matematika. Analisis keefektifan menggunakan uji one sample t-test. Sedangkan untuk mengetahui perbandingan keefektifan dari masing-masing perlakuan dilakukan uji univariat. Sebelum dilakukan kedua pengujian tersebut, maka terlebih dahulu dilakukan uji MANOVA dengan melihat nilai signifikansi pada $\left(T^{2}\right.$ Hotteling's) maka pemenuhan asumsi-asumsi multivariat perlu dilakukan. Berikut hasil analisis asumsi normalitas dan homogenitas multivariat sebelum dan sesudah perlakuan yang ditunjukkan pada Tabel 5 dan Tabel 6.

Tabel 5. Hasil Uji Normalitas Multivariat

\begin{tabular}{ccc}
\hline Kelas & $\left(\boldsymbol{d}_{\boldsymbol{i}}{ }^{\mathbf{2}}\right)$ Pretest & $\left(\boldsymbol{d}_{\boldsymbol{i}}{ }^{\mathbf{2}}\right)$ Posttest \\
\hline PMRI-KoinBilangan & $47,62 \%$ & $42,86 \%$ \\
PMRI-GarisBilangan & $47,83 \%$ & $60,87 \%$ \\
\hline
\end{tabular}


Tabel 6. Uji Homogenitas Multivariat

\begin{tabular}{ccc}
\hline & Pretest & Posttest \\
\hline Box's M & 5,849 & 5,797 \\
F & 1,849 & 1,832 \\
Signifikansi & 0,136 & 0,139 \\
\hline
\end{tabular}

Hasil analisis menunjukkan bahwa semua data untuk pretest dan posttest pada kelas PMRI-Koin Bilangan dan PMRI-Garis Bilangan berdistribusi normal dan kelompokkelompok data terkait berdasarkan uji Box's M memiliki matriks kovarians yang sama. Dikarenakan kedua asumsi terpenuhi maka uji MANOVA dan uji univariat dapat dilakukan. Guna mendukung hasil analisis, berikut ditampilkan dalam scatterplots data pretest pada kelas PMRI-Koin Bilangan maupun PMRI-Garis bilangan.

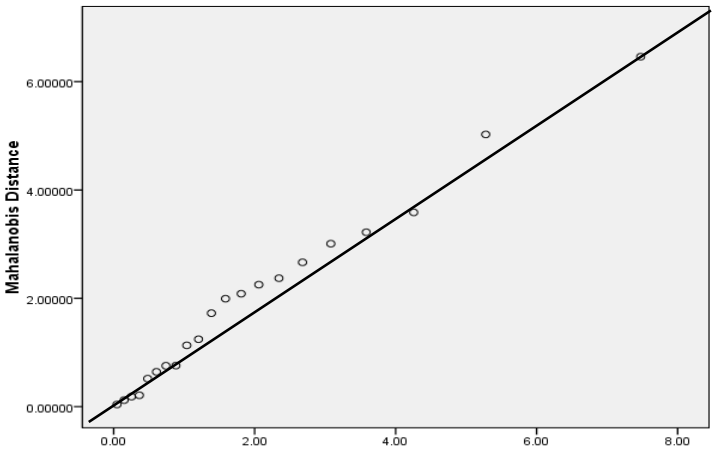

Gambar 1.

Scatterplots Data Pretest Kelas PMRI-Koin Bilangan

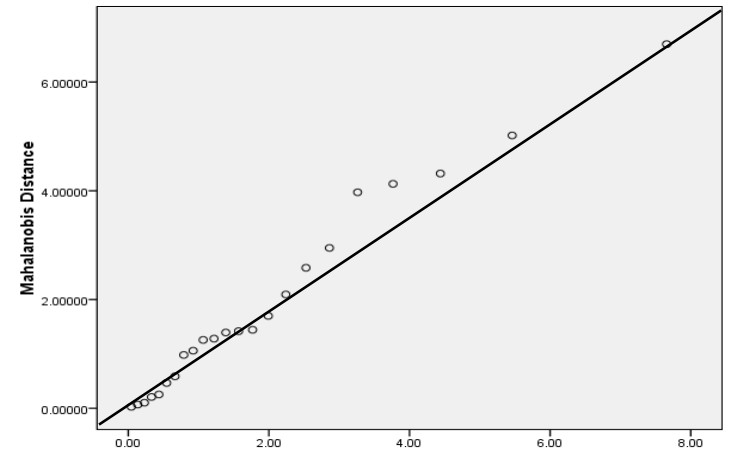

Gambar 2.

Scatterplots Data Pretest Kelas PMRI-Garis Bilangan

Berdasarkan kedua gambar di atas, karena plot membentuk pola garis lurus, maka dapat dikatakan bahwa data pretest kelas PMRI-Koin Bilangan dan kelas PMRI-Garis Bilangan berdistribusi multivariat normal. Sementara untuk mendukung hasil analisis data posttest kelas PMRI-Koin Bilangan maupun kelas PMRI-Garis bilangan akan ditampilkan dalam scatterplots.

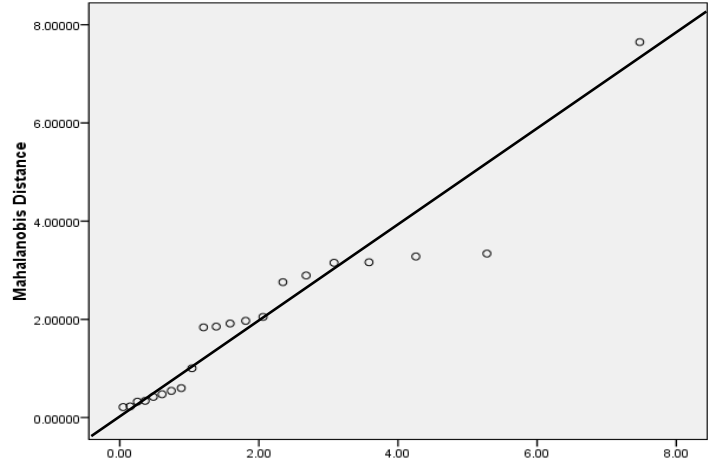

Gambar 3.

Scatterplots Data Posttest Kelas PMRI-Koin Bilangan

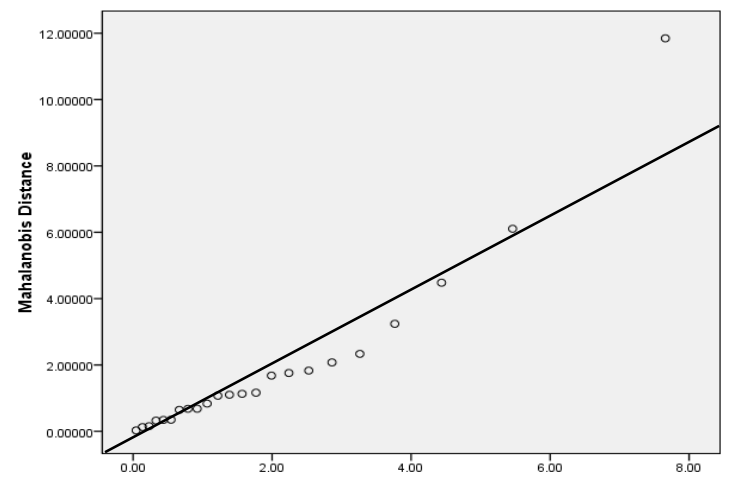

Gambar 4.

Scatterplots Data Posttest Kelas PMRI-Garis Bilangan 
Berdasarkan kedua gambar di atas, karena plot membentuk pola garis lurus, maka dapat dikatakan bahwa data setelah perlakuan (posttest) pada kelas PMRI-Koin Bilangan dan kelas PMRI-Garis Bilangan berdistribusi multivariat normal.

Selanjutnya dilakukan uji MANOVA untuk mengetahui perbedaan rata-rata (mean) masing-masing kelompok sebelum perlakuan maupun setelah perlakuan dengan menggunakan uji $T^{2}$ Hotteling's yang disajikan pada Tabel 7.

Tabel 7. Hasil Uji Manova

\begin{tabular}{ccc}
\hline Uji Multivariat & F & Nilai Sig. \\
\hline Sebelum & 1,857 & 0,169 \\
Setelah & 3,270 & 0,048 \\
\hline
\end{tabular}

Berdasarkan Tabel 7, diperoleh informasi bahwa data sebelum perlakuan (pretest) nilai signifikansi $\mathrm{F}$ lebih besar dari 0,05. Ini menunjukkan bahwa $\mathrm{H}_{0}$ diterima, dengan demikian tidak terdapat perbedaan kemampuan awal siswa antara kedua kelas ditinjau dari prestasi belajar dan tanggung jawab terhadap matematika. Sementara untuk data setelah perlakuan (posttest) diperoleh nilai signifikansi kurang dari 0,05 , maka $\mathrm{H}_{0}$ ditolak. Jadi terdapat perbedaan keefektifan pembelajaran menggunakan PMRI-Koin Bilangan dan PMRI-Garis Bilangan ditinjau dari prestasi belajar dan tanggung jawab terhadap matematika.

Untuk mengetahui keefektifan masing-masing kelompok belajar, maka akan dilakukan uji one sample t-test. Sedangkan untuk mengetahui perbandingan keefektifan dari masing-masing kelompok belajar terhadap prestasi belajar dan tanggung jawab maka dilakukan uji univariat. Uji univariat dilakukan terhadap data-data yang diperoleh setelah perlakuan dengan menghitung nilai t (independent sample t-test). Ringkasan hasil uji one sample t-test dan uji independent sample t-test berturut-turut disajikan pada Tabel 8 dan Tabel 9.

Tabel 8. Hasil Uji One Sample t-test

\begin{tabular}{ccccc}
\hline Kelas & Variabel & $\mathbf{t}_{\text {hitung }}$ & df & Sig. \\
\hline \multirow{2}{*}{ PMRI-KoinBilangan } & Prestasi & 5,063 & 20 & 0,000 \\
\multirow{2}{*}{ PMRI-GarisBilangan } & TanggungJawab & 3,275 & 20 & 0,002 \\
& Prestasi & 3,382 & 22 & 0,0015 \\
& TanggungJawab & 3,595 & 22 & 0,001 \\
\hline
\end{tabular}

Berdasarkan Tabel 8, nilai signifikansi untuk semua aspek pada kedua kelas eksperimen ditinjau dari prestasi belajar matematika dan tanggung jawab terhadap matematika kurang dari 0,05 , ini menunjukkan bahwa $\mathrm{H}_{0}$ ditolak. Artinya pembelajaran PMRI-Koin Bilangan dan PMRI-Garis Bilangan efektif ditinjau dari prestasi belajar operasi hitung bilangan bulat dan tanggung jawab terhadap matematika.

Tabel 9. Uji independent sample t-test

\begin{tabular}{ccccc}
\hline Variabel & $\mathbf{t}_{\text {hitung }}$ & Sig. (2-tailed) & Sig. (1-tailed) & Kesimpulan \\
\hline PrestasiBelajar & 2,411 & 0,020 & 0,01 & $\mathrm{H}_{0}$ ditolak \\
TanggungJawab & 0,353 & 0,726 & 0,363 & $\mathrm{H}_{0}$ diterima \\
\hline
\end{tabular}

Berdasarkan Tabel 9, terlihat bahwa nilai signifikansi prestasi belajar 0,01 $<0,025$ sehingga disimpulkan bahwa $\mathrm{H}_{0}$ ditolak. Artinya, pembelajaran dengan pendekatan PMRIKoin Bilangan lebih efektif dibandingkan pendekatan PMRI-Garis Bilangan ditinjau dari prestasi belajar matematika. Sedangkan untuk aspek tanggung jawab terhadap matematika diperoleh nilai signifikansi 0,363 > 0,025 sehingga disimpulkan bahwa $\mathrm{H}_{0}$ diterima. Artinya pembelajaran dengan pendekatan PMRI-Koin Bilangan tidak lebih efektif atau sama 
efektifnya dengan pendekatan PMRI-Garis Bilangan ditinjau dari tanggung jawab siswa terhadap matematika.

\section{Keefektifan Pembelajaran}

Berdasarkan hasil uji statistik one sample t-test, pembelajaran menggunakan media koin bilangan dengan pendekatan PMRI efektif ditinjau dari prestasi belajar operasi hitung bilangan bulat. Ilustrasi permasalahan kontekstual yang realistik dikembangkan dari kehidupan sehari-hari yang dekat dengan dunia siswa, dijadikan sebagai titik awal pembelajaran matematika untuk mengantarkan siswa mempelajari bilangan bulat. Kent (2000: 4) menjelaskan "meaningful contexts helped these fifthgrade students forge a direct connection between integer concepts and their everyday experiences". Bahwa konteks yang bermakna dapat membantu siswa kelas 5 membentuk sebuah koneksi langsung antara konsep bilangan bulat dengan pengalaman sehari-hari. Melalui media koin bilangan, siswa berpartisipasi aktif selama pembelajaran melalui matematisasi horizontal maupun vertikal untuk mengkonstruksi pengetahuannya dengan memecahkan masalah kontekstual. Tujuannya menemukan konsep terhadap materi bilangan bulat, melalui sintaks pembelajaran PMRI, terutama tahapan penyelesaian masalah kontekstual. Hal ini dikarenakan koin bilangan dijadikan sebagai jembatan dari masalah real ke dalam matematika formal, sehingga memberikan dampak positif terhadap pencapaian prestasi belajar.

Penerapan media koin bilangan sama halnya dengan model Electrical Charges pada operasi hitung bilangan bulat. Keduanya adalah benda konkret berbeda warna yang memvisualisasikan bilangan bulat positif dan negatif. Seperti hasil penelitian Muginah \& Widjajanti (2014: 165) bahwa penggunaan model Electrical Charges dapat meningkatkan keterampilan operasi hitung bilangan bulat siswa kelas V. Manfaat penggunaan koin bilangan adalah siswa mendapatkan pemahaman lebih konkret karena pembelajaran yang dilakukan sesuai dengan tahap perkembangan siswa kelas V SD yang berada pada tahap operasional konkret, dimana tahap ini siswa dapat diajak berpikir secara logis dan mampu memahami contoh-contoh konkret. Diperkuat oleh pendapat Bolyard \& Moyer-Packenham (2012) bahwa penggunaan media koin bilangan efektif terhadap prestasi belajar siswa pada konsep bilangan bulat. Siswa berhasil menerjemahkan antara bentuk representasional bergambar dan tertulis untuk penjumlahan dan pengurangan bilangan bulat. Sama halnya dengan hasil penelitian Badriyah, As'ari, dan Susanto (2017: 56) yang menyatakan bahwa koin bilangan dapat digunakan untuk membantu siswa menyadari tentang kenegatifan bilangan hasil operasi, khususnya operasi hitung bilangan bulat negatif.

Keefektifan pembelajaran menggunakan media koin bilangan dengan pendekatan PMRI ditinjau dari sikap tanggung jawab terhadap matematika dikarenakan sintaks pada pendekatan PMRI. Tahapan seperti menyelesaikan masalah kontekstual, membandingkan dan mendiskusikan jawaban secara individu maupun kelompok. Proses penyelesaian tugas di dalam kelompok, terjadi interaktivitas antar anggota. Interaktivitas merupakan karakteristik dari PMRI. Webel (2010) menyebutkan bahwa proses diskusi tidak hanya berkewajiban untuk menyelesaikan tugas kerja, tetapi juga dapat membangun pemahaman ide baru, sehingga adanya interaksi siswa tidak hanya bertanggung jawab untuk menyelesaikan tugas tetapi berusaha meningkatkan pemahaman dan prestasi belajarnya. Hal ini mengandung arti bahwa perlunya pembelajaran menggunakan pendekatan PMRI yang ditekankan pada keterkaitan antara konsep-konsep matematika dengan pengalaman sehari-hari (Budiharti \& Jailani, 2014: 29).

Pembelajaran menggunakan media garis bilangan dengan Pendekatan PMRI efektif ditinjau dari prestasi belajar operasi hitung bilangan bulat. Sesuai dengan teori Stephan \& Akyuz (2012) penggunaan garis bilangan melalui pendekatan PMRI membantu siswa secara 
signifikan meningkatkan prestasi belajar. Pendekatan matematika realistik membuat skenario pembelajaran yang disajikan sebagai konteks autentik bagi siswa. Sehingga siswa dapat memanfaatkan pengalamannya menggunakan media garis bilangan untuk mengkonstruksi pemahaman konseptual bilangan bulat dan operasinya.

Media garis bilangan dapat mempermudah siswa dalam memahami materi bilangan bulat, dibuktikan dengan hasil penelitian Arifuddin dan Arrosyid (2017: 176) bahwa terjadi peningkatan antara nilai pretest dan posttest, dan penggunaan garis bilangan berpengaruh signifikan terhadap hasil belajar matematika materi bilangan bulat. Peningkatan hasil belajar tersebut dikarenakan penggunaan media garis bilangan yang divariasikan dengan metode demonstrasi. Diperkuat oleh pendapat Steiner (2009: 76) yang menyatakan bahwa media garis bilangan dapat mendukung kemampuan siswa untuk memahami dan menginterpretasi prosedur yang terlibat dalam menjumlah dan mengurangkan bilangan bulat. Dikarenakan siswa dapat memaksimalkan kesempatan untuk belajar dengan cara yang bermakna, di mana prestasi matematika dapat meningkat. Dari uraian di atas, disimpulkan bahwa penggunaan media garis bilangan membantu siswa berpikir logika, yang selanjutnya siswa akan memahami apa yang dimodelkan kemudian menghubungkannya.

Pembelajaran menggunakan media garis bilangan dengan Pendekatan PMRI efektif ditinjau dari tanggung jawab terhadap matematika disebabkan oleh keterlibatan siswa pada tahap penyelesaian masalah kontekstual, membandingkan dan mendiskusikan jawaban. Pada langkah penyelesaian masalah kontekstual, siswa bekerja secara individu yang kemudian diselesaikan secara kelompok. Adanya proses diskusi pada kelompok dapat mengembangkan tanggung jawab. Hal ini dikarenakan akan memunculkan kesadaran (jiwa tanggung jawab) saat memilih keputusan dan melakukan tindakan untuk menyelesaikan LKS berupa permasalahan realistik dengan bantuan media garis bilangan. Disamping itu, masing-masing kelompok membantu satu sama lain, saling berdiskusi, dan menyampaikan ide. Aktivitas demikian yang menunjukkan bahwa garis bilangan memfasilitasi siswa untuk memiliki sikap positif berupa tanggung jawab akan berusaha keras menyelesaikan dan menemukan solusi permasalahan realistik terkait bilangan bulat (Uzel \& Uyangor, 2006). Carpenter \& Pease (2013) menambahkan bahwa pemberian tugas yang relevan dengan bentuk permasalahan logis dan nyata jika dikerjakan secara kolaboratif akan menumbuhkan pola pikir akademik dan memberikan kesempatan untuk bertanggung jawab atas pembelajaran dan perkembangan pengetahuan siswa.

\section{Perbandingan Keefektifan Pembelajaran}

Hasil yang diperoleh melalui uji $T^{2}$ Hotteling's menunjukkan bahwa terdapat perbedaan keefektifan antara kelas PMRI-Koin Bilangan dan kelas PMRI-Garis Bilangan ditinjau dari prestasi belajar dan sikap tanggung jawab terhadap matematika. Adapun hasil uji lanjut yang dilakukan menggunakan uji independent sample t-test diperoleh kesimpulan bahwa pembelajaran menggunakan media koin bilangan dengan pendekatan PMRI lebih efektif dibandingkan menggunakan garis bilangan dengan pendekatan PMRI ditinjau dari prestasi belajar matematika. Jika merujuk pada kajian teori bahwa penggunaan media koin bilangan mampu menyampaikan konsep dengan lebih konkret. Siswa yang lebih dewasa mampu memahami makna lebih baik dari penggunaan koin bilangan daripada garis bilangan.

Kelebihan media koin bilangan lainnya diperkuat oleh Bennett, Burton, \& Nelson (2012: 261) bahwa penggunaan bilangan bulat yang diilustrasikan menggunakan koin bilangan dapat diwakili dalam jumlah tak terbatas. Hal ini mengakibatkan bahwa pada praktiknya, media koin bilangan cukup bersifat efektif dan konkret bagi siswa.

Koin bilangan menekankan pada konsep tentang bilangan kardinal, berarti bahwa bilangan tersebut mewakili sejumlah objek tertentu (Steiner, 2009: 9). Pada operasi 
penjumlahan bilangan bulat berarti menggabungkan atau menjumlahkan koin. Sedangkan operasi pengurangan bilangan bulat berarti memindahkan atau mengambil koin. Sementara garis bilangan menekankan pada konsep tentang bilangan ordinal, berarti bahwa bilangan tertentu mewakili posisi relatif terhadap bilangan lain. Hal ini dikarenakan anak-anak biasanya belajar berhitung jumlah benda sebelum memahami perintah atau posisi mereka. Pemahaman tentang bilangan kardinal datang sebelum pemahaman urutan bilangan.

Praktiknya penggunaan media garis bilangan di dalam pembelajaran kurang efektif. Hal ini dikarenakan aturan penggunaannya yang terlalu rumit bagi siswa. Siswa harus menghafal dan memahami betul aturan penggunaannya sebelum mempraktikkan langsung. Berdasarkan pengamatan, banyak siswa masih keliru untuk menentukan arah maju dan mundur sesuai dengan operasi bilangan bulat yang dikehendaki. Hasil penelitian tersebut sesuai dengan pendapat Bennett, Burton, \& Nelson (2012: 263) bahwa "the number line is a more abstract model for illustrating the addition of positive and negative numbers". Garis bilangan adalah model yang lebih abstrak untuk menggambarkan penjumlahan bilangan positif dan negatif.

Berkaitan dengan aspek tanggung jawab terhadap matematika, diperoleh kesimpulan bahwa pembelajaran menggunakan media koin bilangan dengan pendekatan PMRI tidak lebih efektif atau sama efektifnya dengan pembelajaran menggunakan media garis bilangan dengan pendekatan PMRI. Hal ini Nampak dari hasil angket setelah perlakuan yang menunjukkan hasil yang tidak jauh berbeda antara kedua kelas tersebut. Sintaks pembelajaran kedua media tersebut mengutamakan proses bekerja secara kolaboratif, yang merupakan strategi yang berhubungan erat dengan pendekatan PMRI. Hal ini dipastikan bahwa pembelajaran PMRI harus melibatkan prinsip interaktivitas, terlepas dari bentuk media yang digunakan.

Pada diskusi kelompok terjadi proses interaksi antar siswa, serta antar siswa dan guru yang mengarah pada berbagai jenis komunikasi, diantaranya adalah komunikasi dua arah yang perlu dibangun. Hal ini sejalan dengan hasil penelitian oleh Turmudi (2009) bahwa bekerja secara kolaboratif dan diskusi dalam pembelajaran Realistic Mathematics Education (RME) dapat meningkatkan kemampuan berpendapat dalam matematika dan siswa dapat berbagi ide matematika untuk menemukan solusi permasalahan. Oleh karena itu, kedua pembelajaran tersebut ternyata mampu mengembangkan tanggung jawab siswa, maka keduanya sama-sama efektif ditinjau dari tanggung jawab terhadap matematika.

\section{SIMPULAN DAN SARAN}

Berdasarkan analisis data dan pembahasan, dapat disimpulkan bahwa: (1) pembelajaran menggunakan media koin bilangan dengan pendekatan PMRI efektif ditinjau dari prestasi belajar dan tanggung jawab terhadap matematika; (2) pembelajaran menggunakan media garis bilangan dengan pendekatan PMRI efektif ditinjau dari prestasi belajar dan tanggung jawab terhadap matematika; (3) pembelajaran matematika menggunakan media koin bilangan dengan pendekatan PMRI lebih efektif dibandingkan media garis bilangan dengan pendekatan PMRI ditinjau dari prestasi belajar matematika, namun, sama efektifnya ditinjau dari tanggung jawab terhadap matematika.

Berdasarkan hasil serta temuan penelitian, dan dengan memperhatikan keterbatasan penelitian, maka pembelajaran menggunakan media koin bilangan dan garis bilangan dengan pendekatan PMRI disarankan untuk diterapkan pada proses aktivitas belajar matematika siswa. Penelitian yang dilaksanakan dalam waktu lebih panjang dan optimal memungkinkan dapat memberikan pengaruh positif dan pemahaman yang lebih baik bagi siswa. 


\section{DAFTAR PUSTAKA}

Arifuddin, A., \& Arrosyid, S. R. (2017). Pengaruh metode demonstrasi dengan alat peraga jembatan garis bilangan terhadap hasil belajar matematika materi bilangan bulat. $A l$ Ibtida, Jurnal Pendidikan Guru MI, 4(2), 165-178. doi: http://dx.doi.org/ 10.24235/al.ibtida.snj.v4i2.1834.

Badriyah, L., As'ari, A. R., \& Susanto, H. (2017). Analisis kesalahan dan scaffolding siswa berkemampuan rendah dalam menyelesaikan operasi tambah dan kurang bilangan bulat. Jurnal Pendidikan: Teori, Penelitian, dan Pengembangan, 2(1), 50-57.

Bennet, Burton, Nelson (2012). Mathematics for elementary teacher a conceptual approach. New York: Mc Graw-Hill.

Bolyard, J., \& Moyer-Packenham, P. S. (2012). Making sense of integer Arithmetic: The effect of using virtual manipulatives on students' represent-tational fluency. Journal of Computers in Mathematics and Science Teaching, 31(2), 93-113.

Budiharti, B., \& Jailani, J. (2014). Keefektifan model pembelajaran matematika realistik ditinjau dari prestasi belajar dan kreativitas siswa sekolah dasar. Jurnal Prima Edukasia, 2(1), 27-41. doi: http://dx.doi.org/10.21831/-jpe.v2i1.2642.

Carpenter, J. P., \& Pease, J. S. (2013). Preparing students to take responsibility for learning: the role of non-curricular learning strategies. Journal of Curriculum and Instruction (JoCI), 7(2), 38-55.

Johnson, R. B., \& Christensen, L. (2014). Educational research: quantitative, qualitative, and mixed Approaches $5^{\text {th }}$ edition. Los Angeles: Sage Publication, Inc.

Kent, L. B. (2000). Connecting integers to meaningful contexts. Mathematics Teaching in the Middle School, 6(1), 62.

Muginah, M., \& Widjajanti, D. (2014). Peningkatan keterampilan hitung bilangan bulat melalui metode electrical chargers pada siswa kelas V sd. Jurnal Prima Edukasia, 2(2), 164-174. doi: http://dx.doi.org/10.21821/-jpe.v2i2.2716.

Saifuddin Azwar. (2011). Tes prestasi: Fungsi dan pengembangan pengukuran prestasi belajar. Yogyakarta: Pustaka Belajar.

Steiner, C. J. (2009). A study of pre-service elementary teachers' conceptual understanding of integers. Disertasi doktor, Kent State University, Ohio.

Stephan, M., \& Akyuz, D. (2012). A proposed instructional theory for integer addition and subtraction. Journal for Research in Mathematics Education, 43 (4), 428-464.

Turmudi. (2009) Students' responses to the realistic mathematics teaching approach in junior secondary school Indonesia. Indonesia University of Education. Proceedings of IICMA. 
Awal Nur Kholifatur Rosyidah \& Hartono

KEEFEKTIFAN MEDIA KOIN BILANGAN DAN GARIS BILANGAN MENGGUNAKAN

PENDEKATAN MATEMATIKA REALISTIK

Uzel, D., \& Uyangor, S. M. (2006). Attitudes of 7th class students toward mathematics in realistic mathematics education. International Mathemati-cal Forum, 1, No. 39, 19511959.

van de Walle, J. A. (2008). Matematika sekolah dasar dan menengah pengembangan pengajaran, Jilid 2. (Terjemahan Suyono). New Jersey: Pearson Education (Buku asli diterbitkan tahun 2007).

Wijaya, Ariyadi. (2012). Pendidikan mate-matika realistik suatu alternatif pendekatan pembelajaran matematika. Yogyakarta: Graha Ilmu.

Webel, C. (2010). Collective cognitive responsibility in the high school mathematics classroom. Disertasi doktor, University of Delaware, Newark, Delaware.

Widyastuti, N., \& Pujiastuti, P. (2014). Pengaruh pendidikan matematika realistik indonesia (pmri) terhadap pemahaman konsep dan berpikir logis siswa. Jurnal Prima Edukasia, 2(2), 183193. doi:http://dx.doi.org/10.21831-/jpe.v2i2.2718.

Zulkardi. (2002). Developing a learning environment on realistic mathematics education for Indonesia student teachers. Disertasi doktor, University of Twente, Enschede, Den Haag. 